\title{
TROPICAL MEDICINE
}

\section{New Periodical}

"Annals of Tropical Medicine and Parasitology." Issued by the Incorporated Liverpool School of Tropical Medicine. Edited by Prof. Ross, in collaboration with Drs Stephens, Todd, Thomas and Breinl, Mr Newstead, and Sir Rubert Boyce.

The "Annals," of which the first number will appear early in 1907, will replace the series of separate Memoirs of the Liverpool School of Tropical Medicine, twenty-one of which have hitherto been published by the School (ten Memoirs with 640 pages and 49 plates and figures within the last two years).

The subscription for the "Annals" is ten shillings and sixpence a year, post free, and the subscription for 1907 should be forwarded at once to the Secretary, Liverpool School of Tropical Medicine, B 10, Exchange Buildings, Liverpool, by those who wish to receive the successive issues as they appear.

\section{ROYAL COLLEGE OF PHYSICIANS OF LONDON}

\section{THE WEBER=PARKES PRIZE AND MEDALS}

\section{Prize of 150 Guineas and Two Silver Medals}

The next Award will be made in 1909, and the Adjudicators have selected as the subject of the Essay for that occasion-

"The Value of Bacterial Products in Protecting against or in

Curing Tuberculous Diseases, with special reference to Pulmonary Tuberculosis in Man."

The Essay must be based on original work and observations (experimental or other) of the author, and must include a detailed exposition of the methods employed and their mode of application.

All Essays, together with any preparations made in illustration of them, must be transmitted to the Registrar of the College during the last week of May 1909, in accordance with the Regulations relating thereto, copies of which will be forwarded from the College on application.

The Award will be made on some day previous to the 18th October in that year.

EDWARD LIVEING, M.D., Registrar. 


\section{Publications of the Cambridge University Press.}

\section{Eambrioge BBinlogical Serips.}

General Editor-A. E. SHIPLEY, M.A., F.R.S., Fellow and Tutor of Christ's College.

Zoogeography. By F. E. Beddard, M.A., F.R.S. With Maps. Crown 8vo. 6s.

Elements of Botany. By F. Darwin, M.A., F.R.S. With numerous Illustrations. Crown 8vo. Second Edition. 4s. 6d.

Practical Physiology of Plants. By F. DARwin, M.A., F.R.S. and E. H. ACton, M.A. With Illustrations. Crown 8vo. T'hird Edition. 4s. $6 d$.

Morphology and Anthropology: a Handbook for Students. By W. L. H. Duckworth, M.D., Fellow of Jesus College, Cambridge; University Lecturer in Physical Anthropology. Demy 8vo. 15s. net.

Lectures on the History of Physiology during the Sixteenth, Seventeenth and Eighteenth Centuries. By Sir MichaeL Foster, K.C.B., F.R.S. Demy 8 vo. $9 s$.

The Soluble Ferments and Fermentation. By J. ReynoLds Green, Sc.D., F.R.S., Professor of Botany to the Pharmaceutical Society of Great Britain. Second Edition. Demy 8vo. 12s.

The Natural History of some Common Animals. By Oswald H. LatTer, M.A., Science Master at Charterhouse. Crown 8vo. 5s. net.

The Classification of Flowering Plants. By A. B. Rendle, M.A. (Cantab.), D.Sc. (Lond.), F.L.S., Assistant in the Department of Botany, British Museum.

Vol. I. Gymnosperms and Monocotyledons. Demy 8vo. 10s. $6 d$. net.

The Vertebrate Skeleton. By S. H. Reynolds, M.A., 'Irinity College. Crown 8vo. With numerous Illustrations. 12s. $6 \mathrm{~d}$.

The Origin and Influence of the Thorough-bred Horse. By W. Ridgeway, M.A., F.B.A., Hon. D.Litt., Disney Professor of Archaeology and Fellow of Gonville and Cuius College. With numerous Illustrations. Demy 8vo. 12s. 6d. net.

Practical Morbid Anatomy. By H. D. Rolleston, M.D., F.R.C.P. and the late A. A. Kanthack, M.D., M.R.C.P. Crown 8vo. $6 s$.

Zoology: an Elementary Text-Book. By A. E. ShIPLEY, M.A., F.R.S. and E. W. MacBride, M.A., sometime Fellow of St John's College, Cambridge, Professor of Zoology in McGill University, Montreal. Second Edition. Demy 8vo. With numerous Illustrations. 10s, 6d. net.

Grasses: a Handbook for use in the Field and Laboratory. By the late H. Marshall Ward, Sc.D., F.R.S., Professor of Botany in the University of Cambridge. With Illustrations. Crown 8vo. 6s.

Trees: a Handbook for Students of Forest Botany. By the late H. Marshall WarD, Sc.D., F.R.S. Vol. 1. Buds and Twigs. Vol. 2. Leaves. Vol. 3. Flowers and Inflorescences. With Illustrations. Crown 8vo. 4s. $6 d$. net each.

A Treatise on the British Freshwater Algæ. By G. S. WES', M.A., A.R.C.S., F.L.S., Lecturer in Botany in the University of Birmingham. Demy 8vo. 10s. 6d. net.

A Manual and Dictionary of the Flowering Plants and Ferns. By J. C. Wrutss, M.A., Gonville and Caius College, Director of the Royal Botanic Gardens, Ceylon. Second Edition. Crown 8vo. 10s. 6d.

LONDON: CAMBRIDGE UNIVERSITY PRESS WAREHOUSE, FETTER LANE.

C. F. CLAY, Manager. 


\section{PAUL ALTMANN,}

47, Luisen-Strasse,

Ecke Schumann-Strasse, BERLIN, N.W., GERMANY,

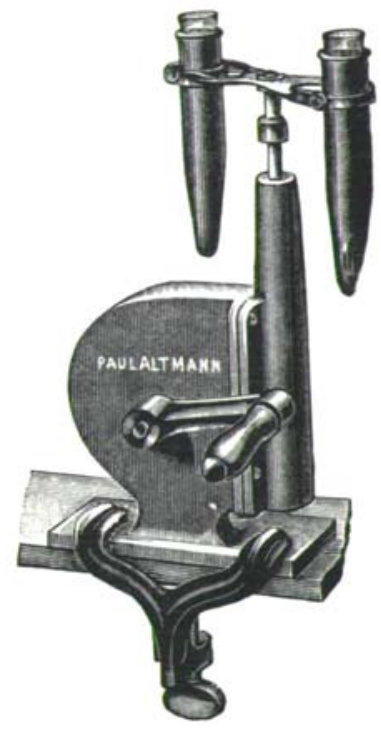

Price : 22 Marks.
Manufacturer of all kinds of apparatus and appliances for Chemistry, Bacteriology, Microscopy and Hygiene.

All Goods manufactured in our own workshops.

COMPLETE OUTFITS of Bacteriological-Microsco. pical and Hygieno-Chemical Laboratories.

\section{SPECIALITY :}

Disinfecting and Sterilising Apparatus.

Thermostats, adjustable for a Constant Temperature. Autoclaves, Centrifugals. Apparatus for Clinical Laboratories, etc., etc.

Full Illustrated Price Lists on Application.



\section{SCIENTIFIC APPARATUS}

JOHN J. GRIFFIN \& SONS, Ltd., KINGSWAY, LONDON, W.C.

Makers to the Admiralty, War Office, India, Colonial and Foreign Governments.

Every facility for making Apparatus to Original Specifications.

ENQUIRIES SOLICITED.

SOLE DEPÔT FOR KAHLBAUM'S CHEMICALS.

Price-list post-free on application.

\section{A HISTORY OF EPIDEMICS IN BRITAIN}

By CHARLES CREIGHTON, M.D., M.A.

Vol. 1. from A.D. 664 to the Extinction of the Plague in 1666. pp. xii + 706. Demy 8vo. $18 s$.

Vol. II. from the Extinction of the Plague to the Present Time. pp. xii +883 . Demy 8vo. 20s.

"An important contribution to British epidemiology." British Medical Journal.

"The immense amount of detail is dealt with by a masterly hand, and we can recommend it most strongly to our readers." Edinburgh Medical Joumal.

LONDON: CAMBRIDGE UNIVERSITY PRESS WAREHOUSE, FETTER LANE. 


\section{Cambridge University Press}

\section{REPORTS ON PLAGUE INVESTIGATIONS IN INDIA}

ISSUED BY THE ADVISORY COMMITTEE APPOINTED BY THE SECRETARY OF STATE FOR INDIA, THE ROYAL SOCIETY, AND THE LISTER INSTITUTE.

(Forming three extra numbers of the Journal of Hygiene: vol. vI. no. 4, Price $6 s$. net.; vol. vII. no. 3 , Price $6 s$. net.; and vol. VII. no. 6, Price 6s. net.)

\section{From the Introduction to first Extra Plague Number.}

"The work which the Commission, appointed by the Advisory Committee, is at present undertaking includes epidemiological observations in the field as well as laboratory experiments, and is being carried on both in Bombay City and in two isolated villages in the Punjab. Attention is for the most part directed to a study of the epizootic spread of plague among rats, the precise relationship of the epizootic to the epidemic, and the modes by which the disease may be communicated from rat to man. The publication of the final conclusions of the Commission on these subjects must be necessarily delayed, since observations are in some instances being carried on continuously throughout a complete period of twelve months, and even after this the analysis of the mass of epidemiological data obtained will occupy a considerable time. A number of contributory investigations, more or less complete in themselves, have, however, reached a stage when it has been considered advisable that they should be made public. It has, therefore, been decided to publish an account of them as a series of independent researches in the form of a preliminary report, without waiting for the full discussion of the conclusions to which they seem to point. Similar reports will be published subsequently from time to time."

Journal of Hygiene, vol. vi. no. 4. September 1906. Price 6s. net. Royal 8vo. pp. 126. With 6 Plates and 6 Folding Tables.

Introduction

\section{CONTENTS.}

I. Experiments upon the transmission of plague by fleas

Part I. Historical introduction

, II. Transference from rat to rat

"III. Experimental production of epidemics among guinea-pigs. (One figure in text)

, IV. Experiments in plague houses in Bombay (Folding Tables I-IV)

II. Note on the species of fleas found upon rats, MIus rattus and Mus decumanus, in different parts of the world, and on some variations in the proportion of each species in different localities. By the Hon. N. Charles Rothschild

III. The physiological anatomy of the mouth-parts and alimentary canal of the Indian rat Hea, Pulex cheopis, Rothschild

IV. On the effect upon virulence of passage of B. pestis through rats by subcutaneous inoculation without intermediate culture

V. On the effect upon virulence of passage of $B$. pestis through rats by cutaneous inoculation without intermediate culture

VI. A note on the immunity of Bombay rats to subcutaneous injection of plague cultures

VII. On the infectivity of floors grossly contaminated with cultures of $B$. pestis

VIII. On the number of plague bacilli in the blood, urine, and faeces respectively of rats which had died of plague

IX. On the quantitative estimation of the septicaemia in human plague

$\mathrm{X}$. On the existence of chronic plague in rats in localities where plague is endemic 
Journal of Hygiene, vol. vil. no. 3. July 1907. Price 6s. net. Royal 8vo. 2p. 154. With 6 Plates.

\section{CONTENTS.}

XI. The diagnosis of natural rat plague

XII. The pathological histology of the spleen and liver in spontaneous rat plague, with observations on the experimental infection. By J. C. G. Ledingham, M.B., B.Sc., M.A.

XIII. Transmission of plague by feeding rats with infected material

XIV. On the significance of the locality of the primary bubo in animals infected with plague in nature

$\mathrm{XV}$. Further observations on the transmission of plague by fleas, with special reference to the fate of the plague bacillus in the body of the rat flea ( $P$. cheopis)

XVI. Experimental production of plague epidemics among animals. (Second Communication)

XVII. Experiments in plague houses in Bombay. (Second Communication)

XVIII. On the external anatomy of the Indian rat flea ( $P$. cheopis), and its differentiation from some other common fleas

XIX. On the natural occurrence of chronic plague in rats

$\mathrm{XX}$. A note on man as a host of the Indian rat flea (P. cheopis)

Journal of Hygiene, vol. viI. no. 6. December 1907. Price 6s. net. Royal 8vo. pp. 302. With 23 Plates, and 76 Maps and Charts.

\section{CONTENTS.}

XXI. Digest of recent observations on the epidemiology of plague

XXII. The epidemiological observations made by the commission in Bombay City

XXIII. Observations made in four villages in the neighbourhood of Bombay

XXIV. General considerations regarding the spread of infection, infectivity of houses, etc., in Bombay City and Island

XXV. Observations in the Punjab villages of Dhand and Kasel

\section{Histological Studies on the Localisation of Cerebral}

Function. By Alfred W. Campbell, M.D., Pathologist to the Asylums Board of the County of Laucaster. With 23 Illustrations in the Text and 29 Plates. Demy 4to. Buckram, 18s. net.

" Dr Campbell's work is most complete and thorough, and of the greatest value to the neurologist. It should be studied by all interested in cerebral function and structure." British Medical Journal.

"This monograph should be read by anatomists, physiologists and pathologists alike." Lancet.

CAMBRIDGE UNIVERSITY PRESS WAREHOUSE,

C. F. CLAY, MaNager.

Zlondon: FETTER LANE, E.C. 


\section{CAMBRIDGE UNIVERSITY PRESS}

Now ready. Royal 8vo. Buckram. pp. xvi+592. Price 18s. net.

\section{IMMUNITY \\ IN INFECTIVE DISEASES}

BY ÉLIE METCHNIKOFF

Foreign Member of the Royal Society of London, Professor at the Pasteur Institute, Paris

TRANSLATED FROM THE FRENCH

By FRANCIS G. BINNIE

of the Pathological Department, University of Cambridge

With 45 figures in the text.

CONTENTS.

Chap. I. Immunity in unicellular organisms.-II. Immunity in multicellular plants.III. Preliminary remarks on immunity in the animal kingdom.-IV. Resorption of the formed elements.-V. Resorption of albuminoid fluids.-VI. Natural immunity against pathogenic micro-organisms.-VII. The mechanism of natural immunity against micro-organisms.VIII. Survey of the facts bearing on acquired immunity against micro-organisms.-IX. The mechanism of acquired immunity against micro-organisms. $-X$. Rapid and temporary immunity against micro-organisms, conferred by specific and normal serums, or by other substances, or by micro-organisms other than those against which it is desired to protect an animal. - XI. Natural immunity against toxins.-XII. Artificial immunity against toxins.-XIII. Immunity of the skin and mucous membranes.-XIV. Immunity acquired by natural means. $-X V$. Protective vaccinations.-XVI. Historical sketch of our knowledge of immunity.-XVII. Summary.

LANCET. - "That a translation of Professor Metchnikoff's valuable and fascinating book on Immunity should be made was most desirable, we might almost say indispensable, and those who may have been deterred from studying the original owing to its being in a foreign tongue will be grateful to $\mathrm{Mr}$ Binnie for the work which he has done.... The book is most interesting reading. ...Study of it is indispensable to all who are specially interested in the subject of Immunity."

\section{CAMBRIDGE GEOGRAPHICAL SERIES.}

General Editor: F. H. H. Guillemard, M.D., FORMERLY LECTURER IN GEOGRAPHY IN THE UNIVERSITY OF CAMBRIDGE.

\section{THE \\ GEOGRAPHY OF DISEASE}

By FRANK G. CLEMOW, M.D. Edin., D.P.H. CAMB., British Delegate to the Ottoman Board of Health, Physician to H.M. Embassy at Constantinople.

Crown 8vo. Cloth. 12 Maps and Charts. Price 15 s.

LANCET.- "Dr Clemow's writings are well known to all epidemiologists and his intimate knowledge of the Russian language has enabled him to study the disease and death records of the vast population of that great European and Asiatic country in a manner which is impossible to most writers....In a preface upon the Geography of Disease and the factors which determine it we find discussed in a fascinating fashion the complex nature of the problem." 


\section{CONTENTS}

(All rights reserved.)

\section{Reports on Plague Investigations in India,}

issued by the Advisory Committee.

(Plates XIX to XLI with seventy-six maps and charts.)

(Continued from Volume VII, p. 476.)

XXI. Digest of recent observations on the epidemiology of plague

XXII. The epidemiological observations made by the Commission in Bombay City . . . . . . .

XXIII. Observations made in four villages in the neighbourhood of Bombay . . . . . . . . . . . 799

XXIV. General considerations regarding the spread of infection, infectivity of houses, etc. in Bombay City and Island . . 874

XXV. Observations in the Punjab villages of Dhand and Kasel

INDEX OF AUTHORS . . . . . . . . . . . . . 987

INDEX OF SUBJECTS . . . . . . . . . . . . . . 990

The Journal of Hygiene is issued quarterly. A volume containing about 500 pages, with plates and figures, is issued annually.

Volumes I, II, and III (1901-3) complete. In Four Parts, paper covers, 15s. net per volume. Bound in buckram, 18s. $6 d$. net per volume.

Volumes IV, V, VI, and VII (1904-7) complete. In Four Parts, paper covers, 21s. net per volume. Bound in buckram, 25s. net per volume.

Papers for publication may be sent to Prof. Geo. H. F. Nutrall, F.R.S., 3 Cranmer Road, Cambridge, or to the associate Editors. Other communications should be addressed to the University Press, Cambridge.

Papers forwarded to the Editors for publication are understood to be offered to the Journal of Hygiene alone, unless the contrary is stated.

Contributors receive fifty copies of their papers free. Additional copies may be had at cost price: these should be ordered when the final proof is returned.

The subseription price is £1. 1s. per volume (post-free), payable in advance; single numbers $7 s$. net. (Plague Numbers, Vol. VI, no. 4, and Vol. VII. no. 3, Price 6s. net. each.) Subscriptions may be sent to any Bookseller, or to $\mathrm{M}_{\mathrm{R}}$ C. F. CLAY, MANAGER, Cambridge University Press Warehouse, Fetter Lablished online by Cambridge University Press 